\title{
9 Toward socially sustainable renewable energy projects through involvement of local communities
}

\author{
Normative aspects and practices \\ on the ground
}

\author{
Karin Buhmann, Paul Bowles, Dorothée Cambou, \\ Anna-Sofie Hurup Skjervedal, \& Mark Stoddart
}

\section{Introduction}

While scientists' warnings about climate change and their calls for urgent action are gradually coming to be accepted by politicians and regulators across the globe, the implications of a warmer climate are particularly fast and acute for the Arctic. This has spurred projects in Arctic countries to shift to low-carbon energy sources, in particular wind, hydro and solar power (Business Index North, 2017; McCauley, Heffron, Pavlenko, Rehner, $\&$ Holmes, 2016). While these forms of energy are renewable and therefore environmentally sustainable in a narrow sense, decisions on their locations have caused a range of protests by local communities including Indigenous groups. The protests are typically fueled by concerns over the social and/ or environmental implications of the projects. On the one hand, the projects may offer jobs and economic development. On the other hand, they are seen as posing new risks for people living in the Arctic. Just because energy sources are renewable, this does not mean they are free from adverse social impacts or that they are regarded as socially acceptable. Developing and storing energy from renewable sources like wind and the sun depends on technical solutions, some of which in turn depend upon minerals, including rare earth elements (REE), copper or cobalt. In many countries, but particularly in the global South, issues of labor conditions and the environmental impacts of mining and the processing of minerals are well-documented. As deposits of such minerals in the global South are becoming depleted, and the Arctic increasingly more accessible due to the changing climate, Arctic countries are emerging as potent sources of minerals for the global production of wind and solar energy technologies and batteries for storing renewable energy. Scaling up renewable energy infrastructure is in line with Sustainable Development Goal (SDG) 13 on urgent action to combat climate change and its impacts, as well as SDG 7 on access to affordable, reliable, sustainable and modern energy for all (UN, 2015a). However, the texts of the Paris Climate Change Accord and the Sustainable Development

DOI: $10.4324 / 9781003172406-9$ 
Goals recognise that the transition to a low-carbon economy should be implemented with respect for human rights (UN, 2015a, 2015b).

There is often a close connection between harmful environmental and social impacts. This is recognised by the inclusion of social aspects in environmental impact assessment processes (Esteves and al., 2012; Nenasheva, Bickford, Lesser, Koivurova, \& Kankaanpaa, 2015). Likewise, the Aarhus Convention (UN, 1998) on public participation in environmental decision-making includes health aspects. The connection carries over into debates on injustice and disproportional burdens carried by certain groups, including Indigenous peoples, in the interest of others (see also the chapter by Cambou and Polzer in this volume). Environmental injustice is a situation where specific social groups disproportionately bear the risks or negative impacts of development projects (Mohai, Pellow, \& Roberts, 2009). Similarly, an emerging energy justice literature defines energy injustice as a situation where the benefits and negative impacts of energy projects are disproportionately distributed and where those who are impacted by energy development are not able to fully participate in the decision making and planning that affects their communities (McCauley et al., 2016). Social expectations as well as national and international legal norms require that renewable energy projects include meaningful engagement with local communities that are or can be affected by a project. With variations across the Arctic, local law and regulations require companies to assess the environmental and other societal impacts of their planned projects and address adverse impacts, while local governments are required to organise consultation processes (Nenasheva et al., 2015). International soft law guidance issued by the United Nations (UN) and OECD require impact assessments and measures to address adverse impacts to be undertaken with meaningful engagement of potential or actual victims of harmful impacts (Buhmann, 2016; Ruggie, 2013). Referring to those whose human rights are or can be adversely affected by projects, the term "affected stakeholders" applied by the UN and OECD instruments includes a strong focus on rights-holders. Public demands to become part of the planning and decision-making processes increase as advances in technology enable access to information on projects and enable those affected to effectively organise to respond to such projects (Buxton \& Wilson, 2013). Such demands reflect an expectation that impact assessments involve stakeholder engagement that is meaningful from the perspective of those affected by the project. Theory and practice recognise that processes for engaging local communities and other affected stakeholders in decisionmaking are conditions for making good decisions (Forester, 1989; Parenteau, 1988; Pearce, Edwards, \& Beuret, 1979; Tauxe, 1995; Webler, Kastenholz, \& Renn, 1995). As exemplified below in the section on stakeholder engagement, experience across the Arctic testifies to the need for stronger engagement by companies and governments with consultation processes in order to identify and address concerns from the local perspective.

The urgency of mitigating climate change and meeting the thresholds of the Paris Climate Change Agreement are legitimate needs recognised by a global 
society. However, when actions taken in response to that urgency are pitched against equally legitimate interests of communities and Indigenous groups related to their traditions and foundations for their own sustainable economies, then complexity increases. Further complexity is added by impacts on employment and rights to participate in decision-making, for example through consultations and other forms of impact assessment involving meaningful stakeholder engagement. Some Arctic countries have recognised the right of Indigenous groups to free, prior and informed consent (FPIC), but others have not. Handling climate change exacerbates moral dilemmas as communities in one area are being placed under social or environmental pressures in the larger global interest. The essence of the moral dilemma is that opposition to a project (for example by an Indigenous community in one place due to risks to their traditional lifestyles) may place other communities in far-away places under increased risk of climate-change-related harm (such as flooding). As one Sápmi leader said in June 2019 to the lead author of this chapter, it is a fundamental moral question that challenges conventional perceptions of balancing interests and rights. This emergent challenge is currently under-researched. This chapter contributes to addressing this gap by exploring the issue of stakeholder involvement in regard to renewable energy projects, in the recognition that involvement is often the key to solving difficult dilemmas.

In a global perspective, research-based knowledge on what makes stakeholder engagement meaningful is limited (Maher \& Buhmann, 2019; Skjervedal, 2018; Zoomers \& Otsuki, 2017). In turn this raises several sub-questions, including what makes a process "good" and how involved organisations can turn formal requirements and top-down approaches into meaningful engagement from the perspective of local communities. We contribute by addressing the issue in an Arctic context, drawing on a series of cases of stakeholder involvement that illustrate varieties of perceptions of processes on the ground, and analysing these against normative foundations. Selected cases from Arctic countries serve to identify what constitutes meaningful stakeholder engagement through "stories" of what works well and what does not work well or is perceived by Arctic communities as inadequate.

The chapter applies an interdisciplinary approach. Grounded within the social sciences, the chapter relies on legal, sociological and general social science and communication studies methods for analysis of political and normative foundations through document-based studies and fieldwork.

\section{Background}

\section{The normative interface between climate change mitigation and socially sustainable economic activities}

On a global scale, a connection between social sustainability and renewable energy is recognised in theory as well as in political agreements on sustainable development. While climate change and adequate responses are pressing 
challenges for all societies, responses involve navigating conflicting social priorities (Hoffmann, 2011; Hulme, 2009). The introductions to the declarations that embody the SDGs and the Paris Climate Change Agreement explicitly note that the transition to a more holistically sustainable and low-carbon economy must be accomplished with respect for social impacts, in particular human rights (UN, 2015a, 2015b). SDG 17 on partnerships explicitly notes that SDG implementation must not cause harm, and the Paris Agreement refers to responsibilities for human rights, including those of affected local communities and vulnerable groups.

The SDG implementation provisions explicitly refer to the United Nations Guiding Principles (UNGPs) on Business and Human Rights (UN, 2011). These are a set of globally applicable guidelines for how states and companies should act to avoid human rights harm related to business operations. Due to the comprehensiveness of human rights, this includes social and many environmental risks or impacts caused by economic activities. Jointly with the "Protect, Respect and Remedy" Framework (UN, 2008) (a UN study which provides a theory-based foundation for business respect for human rights), the UNGPs are considered current state of the art concerning business respect for human rights (Wettstein, 2012). They advance "human rights due diligence" as a management approach for companies to identify and manage their adverse impacts on society. It is clearly stated that impact assessment undertaken as part of the due diligence process should build on meaningful stakeholder consultation, especially with "affected stakeholders," including communities and individuals affected by proposed or actual projects. Under the term "risk-based due diligence," this approach has been adopted by several transnational business governance instruments, including the OECD Guidelines for Multinational Enterprises (OECD, 2011) and the IFC's performance standards which inform the Equator Principles. Applied by more than 30 export credit agencies and more than 90 banks and financial institutions, the Equator Principles have the capacity to influence decisions to fund renewable energy projects in many places, including the Arctic. The OECD's Guidelines apply to companies operating in or out of the currently 48 adhering states. As all Arctic countries except Russia are OECD members, and because the Guidelines' definition of "multinational" is inclusive, the Guidelines cover most companies and institutional investors involved in renewable energy across the Arctic. Testifying to the importance of involving stakeholders as part of the due diligence process, the OECD in 2017 issued guidance for the implementation of the Guidelines for meaningful stakeholder engagement in the extractive sector (OECD, 2017). Underscoring the Arctic relevance, translation into the Sámi language was published in 2019.

\section{Impact assessment and meaningful stakeholder engagement}

Theory and practice on social impact assessment is evolving in response to the confluence of established theory-supported best practice on social 
impact assessment, and emergent normative standards on human rights impact assessment (Vanclay \& Esteves, 2011; Harrison, 2013).

Impact assessment is a process that involves scoping, assessing and mitigating impacts, often implemented through a permit conditional on the impact assessment being undertaken (Esteves, Franks, \& Vanclay, 2012; Vanclay, 2003). Risk-based due diligence has come to be associated with impact assessments because this due diligence approach aims at preventing harm, mitigating harm that is inevitable (typically already occurring), and accounting for processes to do so (UN, 2011; Buhmann, 2018a). Meaningful stakeholder engagement is an integral element in a sound impact assessment process as well as in activities to monitor, follow up and adjust action to prevent or mitigate adverse impacts. As the OECD Guidance (2017:18) notes, "Stakeholders themselves can contribute important knowledge to help identify potential or actual impacts on themselves or their surroundings. The values and priorities of impacted stakeholders are vital considerations in evaluating impacts and identifying appropriate avoidance or mitigation steps."

Indeed, stakeholder participation is an essential qualitative component of an impact assessment process (Nenasheva et al., 2015). Involving affected stakeholders in line with the normative foundations of the UNGPs and the OECD Guidelines means that communities affected by projects related to renewable energy should be consulted in a meaningful manner, and their concerns addressed. Explicating implications for specific contexts, implementation guidance for the IFC performance standards notes, i.a., that

Nomadic peoples may have rights - whether legal or customary - to pass through client-controlled land periodically or seasonally, for subsistence and traditional activities. Their rights may be linked to certain natural resources such as [...] herds of migratory animals [...]. In its due diligence, the client should establish whether nomadic peoples have such rights, and, if possible, with the safeguards mentioned above, the client should allow them to exercise these rights on company-controlled land.

(IFC, 2012, GN63)

Aiming to prevent social harm, risk-based due diligence differs from conventional financial or legal due diligence that firms have long performed with the aim of preventing harm to the firm (Buhmann, 2018a). Meaningful stakeholder engagement with affected communities can benefit not only the community but also the involved company and government agencies (Udofia, Noble, \& Poelzer, 2017). If done well it can help companies retain a "social licence to operate" that facilitates current and future operations and expansions, contributes to early identification of risks of adverse impacts at the site of operations or supply chains, and helps avoid the costs of conflict arising from lost productivity due to temporary shutdowns and senior personnel time being diverted to manage grievances (OECD, 2017, p. 14; Ruggie, 2013; Kapoor, 2001). 
In some Arctic countries environmental impact assessments include broader societal aspects, such as impacts on health, employment, traditions and business operations (Nenasheva et al., 2015). Explicitly granted for Indigenous populations by ILO Convention 169, stakeholder engagement may be considered an extension of the human rights to participation in public decision-making affecting one's life (Mestad, 2002). Applying to environmentally related social issues, the Aarhus Convention grants citizens a right to popular participation that includes access to information, access to dialogue with authorities granting permits, and access to remedy. Yet, despite the international and national normative framework for stakeholder engagement, several recent incidents across the Arctic demonstrate that stakeholders often do not perceive their involvement in processes related to renewable energy to be adequate or meaningful.

Proposed or implemented mining projects have led to local conflicts in Northern Scandinavia (Bjørst, 2016; Hansen, Vanclay, Croal, \& Skjervedal, 2016; Lindahl, Johansson, Zachrisson, \& Viklund, 2018). Studies from other regions show that such conflicts can be devastating to the local community and undermine support from other stakeholders (Bebbington et al., 2008; Rodríguez-Labajos \& Özkaynak, 2017). The adequacy of involvement by local communities and Indigenous groups and peoples in Arctic economic development projects has been questioned (Abram, 2016; Cambou, 2018). In Eastern Canada, protests around large-scale hydro-power projects testify to concern with environmental health and safety risks to Indigenous communities in Labrador and Newfoundland. In British Columbia, First Nations and others have protested the consultation processes and impacts related to various renewable energy projects. This is also the case in northern FennoScandinavia, where Sámi communities have challenged decisions concerning the establishment of local wind project. In Greenland, new ideas have surfaced for involving youths in decisions that will ultimately affect their futures. In the following sections, we provide more details on some of these conflicts and developments concerning meaningful stakeholder engagement.

\section{Stakeholder engagement on the ground}

\section{Sápmi}

In Norway and Sweden, Indigenous involvement in energy projects in the Arctic parts of those countries has been a question of controversy for many years. Historically, large-scale hydroelectric projects spurred the first open conflicts between the Nordic governments and the Sámi people (Cambou $\&$ Polzer, 2020). In this context, the involvement of Sámi communities was often overlooked and their traditional livelihoods seriously impaired by the development of energy projects promoted by the nation states.

In the twenty-first century, the situation of the Sámi people has significantly evolved as a result of the adoption of international and national laws 
recognising their rights as a minority and an Indigenous people (Allard \& Skogvang, 2017; Bankes \& Koivurova, 2013). Yet, the impacts of projects related to a low-carbon transition continue to jeopardise their traditional livelihoods. In Northern Norway, the Nussir copper mine epitomises the dilemma faced by the Government of Norway between protecting the pristine ecosystem and providing the country with a mineral required for batteries for electric cars. However, for local Sámi reindeer herders, the project also means the potential loss of reindeer herding grazing pastures and the disturbance of the migration of reindeer and salmon fishing grounds (Koivurova et al., 2015, p. 32). The Sámi Parliament in Norway has opposed the Nussir project due to the lack of consultation with Sámi communities at the local level (Storholm, 2016). According to the UN Rapporteur on the Rights of Indigenous Peoples, Norwegian law does not comply with international standards on the rights of Indigenous peoples concerning consultation on the basis of the principle of FPIC (Human Rights Council, 2016, para. 29).

The expansion of wind power also highlights contestation over the rights of the Sámi people and what is entailed by meaningful stakeholder engagement. The rise in wind energy projects to advance ambitious national climate goals has raised important concerns among Sámi reindeer herding communities. The establishment of several wind energy projects, often largescale, has been contested due to their adverse effects on reindeer pasture and migration (Cambou, 2018). Sámi reindeer herding communities have criticised and lodged legal protests against such projects due to their lack of meaningful consultation or loss of income due to participation in consultations (Cambou, 2018; Buhmann, 2018b). They also oppose wind energy projects because they do not benefit their communities and paradoxically also threaten the sustainability of their traditional livelihoods. Decisions by courts note the need for a collaborative effort to overcome the potential difficulties associated with the co-existence of both activities. Related to a Norwegian wind turbine project affecting a Sámi village in Sweden, the complaints institution to the OECD Guidelines underlines the responsibility of the company to engage with Sámi reindeer herding communities as a means to prevent and mitigate the adverse impact of wind projects (OECD Watch, 2012; Buhmann, 2018a).

These considerations underscore the need for ensuring the meaningful involvement of Sámi communities within energy and industrial projects located on their traditional lands in order to guarantee that they also reap some of the benefices of the energy transitions.

\section{Greenland}

Public participation in Greenland displays a contrast between solid national regulation and institutions, on the one hand, and the lived experience of meaningful stakeholder involvement, on the other (Olsen and Hansen, 2014). The changing climate has renewed interest in exploration and exploitation of 
mineral resources, including hydrocarbons. The Government of Greenland is determined to make extractives a primary business sector, in close collaboration and dialogue with the country's population (Government of Greenland, 2016, 2019).

Part of the Danish Kingdom, since 2009 Greenland has self-government with full decision-making powers in policy areas that have been claimed. Whereas the Inuit population, which forms the country's majority, can be argued to be entitled to special protection under international law as an Indigenous people in regard to decisions made by the Danish Government, the same does not apply to decisions made by Greenlandic authorities.

While renewable energy projects in Greenland are emergent (Nukissiorfiit, 2019), the mining sector offers insights on differences between formal requirements on stakeholder involvement and community perceptions of what constitutes meaningful stakeholder engagement. The mining sector is re-emerging decades after aluminum and coal extraction closed down (Sejersen, 2014).

Greenland has not acceded to the Aarhus Convention but national policy and legislation sets high goals for public participation. In the Mineral Resources Act Greenland's self-government has introduced explicit social sustainability assessment requirements for certain raw-material extraction projects (Hansen et al., 2016). The Social Impact Assessment Guidelines issued by the government refer to stakeholder involvement as a prerequisite for a good impact assessment process to promote sustainable development in Greenlandic society (Government of Greenland, 2016). Whereas the political, scientific and public debate on mineral extraction in Greenland has been extensive in the past decade, only two mines are currently operational (a ruby mine by a settlement of 235 inhabitants, and an aluminium mine located at some distance from settled areas). However, proposals to establish an iron mine (Isua) in the Nuuk fjord close to Greenland's capital and a REE mine (Kuannersuit) by Narsaq town in Southern Greenland have sparked extensive public debate on stakeholder influence, which provides insights on what makes stakeholder involvement meaningful. The Isua project led to strong public mobilising to protect the fjord, led by organised civil society groups (Nuttall, 2012). The project was eventually called off for reasons that also included economic viability. The Kuannersuit project is still under consideration and closer to the granting of an exploration license than some nearby smaller REE deposits. Kuannersuit stands out by containing $10 \%$ uranium that will be an unavoidable by-product of exploration. This has generated concern with impacts on human and animal health among some locals, in particular sheep farmers, whereas others welcome prospects for employment. Although consultations have occurred according to formal requirements, frustration nevertheless resulted with some sheep-farmers and others in the local community having a sense that the process was not accessible because of their locations or due to work requirements. The frustration was aggravated by the insecurity caused by the risk of uranium dust and uncertainty of actual health impacts (Buhmann et al., 2019/2020). This example shows that conducting impact assessments by the 
book is not enough if consultation meetings are seen to be inaccessible, and that complex technical and health implications must be explained in a manner that makes sense from the perspective of the audience (i.e.Cunsolo \& Ellis, 2018).

The Nordic Council has a policy of involving youth. However, studies show a lack of focus on engaging young people in Greenland. Such oversight may cause young people to miss out on having a say on project development that will affect their futures. It may also reduce their access to relevant information to plan for the future in terms of education and employment opportunities. Research demonstrates that the use of social media as a complementary communication channel enables young people to engage in project development in a manner that is meaningful to them (Skjervedal, 2018). Capturing their interests, values, fears, hopes and aspirations for the future along with their thoughts on future extractive development in Greenland, this approach engaged a wide range of youth across Greenland in a manner they perceived as meaningful. Providing a "safe forum" for active and collaborative engagement, social media allowed youths to engage in their own time in a manner aligned with how this age group normally communicate and share information on a daily basis (Skjervedal, 2018).

These observations highlight the need for applying methods that are appropriate and relevant to specific types of stakeholders and tailoring the participation form(s) to the specific project, local context, and target groups.

\section{Canada}

While the Eastern (Atlantic) Canadian province of Newfoundland and Labrador sits well below the Arctic Circle, Labrador is often defined as a northern place due its landscape and histories of inhabitation by Inuit, NunatuKavut, and Innu communities (Proctor, Felt, \& Natcher, 2012). The province is the site of the 1990s cod fishery collapse, regarded by many as one of the worst ecological disasters in Canadian history (Bavington, 2010). In the decades since the cod fishery collapse, the provincial political economy reoriented around offshore oil extraction. Given the dominance of oil development in provincial politics and the public imaginary, it is unsurprising that the province tends to resist federal government moves toward stronger climate policy, downplaying the responsibility of the oil sector and other large industry (Sodero \& Stoddart, 2015).

This sets the context for understanding renewable energy transitions in Newfoundland and Labrador. Public discourse and planning has been dominated by the large-scale Muskrat Falls hydro-electric project. This new dam is located on the lower Churchill River in Labrador and involves a link across the Labrador Straits to the island of Newfoundland where it will feed into the provincial energy system. Muskrat Falls will allow the province to meet its energy needs while decarbonising the provincial energy system and meeting its climate change goals (Nalcor Energy, 2020). 
The project has generated considerable controversy and contention, especially from downstream Indigenous communities, including the grassroots movement known as the Labrador Land Protectors. The process of planning and approving the Muskrat Falls dam was handled by the provincial government in partnership with Nalcor, the public energy corporation. Many opponents of the project have argued that Indigenous communities were not appropriately consulted or engaged in the process of planning and implementing this project, especially as environmental health concerns were still being researched and documented as the project was approved (Allen, 2017).

The negative impacts of Muskrat Falls are not only financial, which have been the main focus of a public inquiry. There are significant downstream environmental health risks. There are concerns that methylmercury from rotting vegetation inside the dam reservoir will flow downstream and contaminate fish and wildlife populations. Fish and game remain integral to Indigenous community diets and cultural traditions. The ability to retain land-based food culture is essential in a region where high food costs and food security are serious issues (Cox, 2019b; Penney, 2018). There are also concerns around slope stability related to the dam infrastructure. If dam infrastructure fails and collapses, then downstream communities will be flooded, which is a source of fear and stress (Cox, 2019a; Philpott, 2018).

Opposition to the project and calls to "Make Muskrat Right" have taken the form of hunger strikes and grassroots protest by the Labrador Land Protectors and their allies at the Muskrat Falls site, as well as at the provincial legislature in St. John's and other locations around the province (Allen, 2017; Cox, 2019a, 2019b). On-site protests have used civil disobedience, which has been met with arrests and imprisonment for breaching court orders that restrict access to the work site. Land Protector Denise Cole has described protest as "an act of ceremony" and as a responsibility to Indigenous laws as it rejects a view of Labrador as a resource warehouse for Newfoundland and bears witness to the destruction of sacred spaces (Cole, 2018). Grassroots opposition has been amplified by formal representatives of Indigenous communities, though there were also divergent responses from various community leaders (Doherty, 2018).

The Muskrat Falls project is an example of environmental injustice and energy injustice, as downstream Indigenous communities are being asked to bear the health costs and safety risks of a mega-project that is being promoted as a provincial climate change solution and core part of a renewable energy transition (Municipal Affairs and Environment: Climate Change Branch, 2011).

In contrast to Newfoundland and Labrador, British Columbia (BC) in Western Canada is historically a province that relies heavily on renewable energy. The province gets approximately $95 \%$ of its power from renewables with hydroelectricity accounting for about 85\% (National Energy Board, 2018) and so it is widely seen as a "green energy" province. The environmental movement has been strong in the province for many decades, 
indeed the "global environmental movement started in British Columbia" (Byers, 2012), and, in 2008, it became the first jurisdiction in North America to introduce a carbon tax.

Despite these contrasts with Newfoundland and Labrador there are also striking similarities. Just as the Muskrat Falls hydro project raised questions of environmental injustice and environmental racism in its treatment of Indigenous peoples, so the same issues are evident in BC's hydro projects. The WAC Bennet dam, constructed in the Peace river region of northern BC in the 1960s, is a major contributor to hydropower but was built without the local Indigenous population of Kwadacha being informed, let alone consulted. Their traditional territory was flooded when Williston reservoir, the world's seventh largest, was formed. The livelihoods of Indigenous individuals and groups were destroyed with the Kwadacha community forgotten in the push to develop the power source that would drive industrialisation and resource extraction in the northern part of the province (Loo, 2007; Stanley, 2010). The community was promised electricity as part of the project but this was never honored.

This sets the historical background for the construction of the Site C dam in the same geographical area today, designed to further increase hydro capacity. The approval of this project has also proved to be contentious. While consultation processes did take place and there have been significant improvements since the 1960s when the WAC Bennet dam was constructed, Site $\mathrm{C}$ was opposed by a coalition of Indigenous groups, farmers and environmentalists (Cox, 2018a). It is still subject to on-going legal challenge by the West Moberly and Prophet River First Nations with West Moberly First Nation's Chief declaring the project "cultural genocide" (Cox, 2018b). The various review processes have been widely criticised as politically driven and biased in the knowledge that they viewed as important (Bakker \& Hendriks, 2019; Muir, 2018).

Again, similar to the Newfoundland and Labrador case, the project was initiated by one government and reluctantly approved by a new one on the grounds that sunk costs made cancellation too costly. Even when the economic case for the project and the impacts on Indigenous relations are recognised as problematic, once started, these mega-projects become difficult to halt. This reinforces the need for the initial consultation processes to be thorough, transparent and seen as legitimate by all stakeholders and rights holders.

A further complicating factor with the Site $\mathrm{C}$ dam is that unspecified amounts of electricity from the dam will be used to develop BC's emerging liquefied natural gas (LNG) export industry. Ironically, the expansion of renewable energy will support the expansion of fossil fuel production, in the form of LNG, rather than to replace it. The development of renewables around the Arctic therefore has also to be seen in the context of what the renewable energy will be used for, a question which has also arisen in the case of the uranium that will be a by-product from the Kuannersuit mine in Greenland. 
Hydro mega-projects have proven too often be contentious but there are smaller renewable energy projects which are much less so, including many involving First Nations. These include attempts by off-grid First Nations to replace diesel with renewables such as solar power as in the case of the T'Sou-Ke First Nation (Bhattacharya, 2017). Several local governments and Band Councils in Haida Gwaii, an island off British Columbia's northwest coast, have been active in plans to reduce reliance on diesel and move to renewable energy sources. ${ }^{1}$ The key to these projects is that they have been initiated and led by local communities themselves. Higher level governments have often been facilitators by supplying needed financial support but the decision-making has been local community based. This provides a quite different model of community involvement and empowerment than occurs with renewable energy mega-projects.

\section{Implications for planning and implementing socially sustainable renewable energy projects}

These examples underscore the need to take social sustainability seriously in discussions and analyses of how to promote renewable energy in Arctic countries. This must be central in plans to expand renewal energy to both address climate change and provide new economic opportunities.

The Muskrat Falls controversy highlights how renewable energy transitions can produce new energy injustices for local communities, in particular in the Arctic context northern Indigenous communities. Some of these, including Indigenous communities in Labrador, are already experiencing the harmful impacts of climate change more acutely than elsewhere in the country.

The Canadian cases also show that scale is an important factor in the quest for genuine community participation, involvement and ownership of renewable energy projects. Community participation in a way that appears meaningful to those affected has proven to be more feasible for smaller projects. It remains a pressing issue whether and how this can be scaled up for larger projects which may contribute more to combat the urgency of the global climate crisis.

The case of the Sámi people also highlights how the development of industrial and energy projects promoting sustainable development can paradoxically jeopardise the sustainable livelihoods of Indigenous peoples. The lack of meaningful consultation of Sámi communities continues to loom large in the debate concerning the development of energy projects on their traditional lands and questions the adequacy of the legal framework of the Nordic countries to guarantee their rights as an Indigenous people. This case also demonstrates the need to integrate energy justice considerations in order to ensure a transition to renewable energy and economies that are socially sustainable and just for all. 
One of the first states to sign the ILO Convention 169, Norway was early to recognise the principle of FPIC. Yet, despite important legislative changes, the lack of meaningful consultation with the Sámi people concerning the development of industrial and energy projects on their traditional lands remains problematic. The Nussir mine case illustrates the problem when stakeholder consultation is perceived as an empty process. On the one hand, the Sámi cases demonstrate the need to improve legislative frameworks that ensure that the rights of the Sámi people as an Indigenous people are protected and respected by states and companies, especially when decision and measures concerning energy projects affects them. On the other, the Sámi and Greenlandic cases demonstrate that for stakeholder engagement to be meaningful, formal legislation must be matched by implementation and planning of consultations that respect existing commitments of affected stakeholders.

The Greenland case also highlights how broadening the range of forms of public participation can increase the perception of consultations as meaningful for those involved. Opportunities for a broad representative voice among local communities can be provided through tailoring the participation form(s) to the specific project, local context, and target groups, with a focus on creating a "safe forum' for active and collaborative engagement.

The social legitimacy of renewable energy projects and the public and private organisations behind them require careful planning to avoid such injustices. This is a problem across the globe, but its acuteness hits strongly in the Arctic, exacerbated by past injustices between colonial settlers and Indigenous groups that with variations apply to all the areas discussed above. Moreover, the rise of conflicts in rule-of-law based Arctic states discomfortingly reminds us of conflicts that scholars and practitioners in the North often associate with countries with weak governments. Yet the Sápmi, Greenland and Canadian cases above all demonstrate that the transition from the ideals of meaningful stakeholder involvement, expressed in the globally applicable UNGP and elaborated through the OECD Guidelines and related guidance texts, is easier said than done. Moreover, the Greenland example illustrates that even where local law and regulations aim to ensure at a high level of stakeholder involvement, the experienced effects may be different. Jointly, the cases demonstrate that meaningful stakeholder engagement from the perspective of those affected is a core element in upholding energy justice and environmental justice in order to ensure that climate change solutions do not amplify other forms of social inequality. This also confirms findings from studies in a Global South context (for example, Maher \& Buhmann, 2019; Zoomers \& Otsuki, 2017) that more research is needed on how to transform formal - and often well-intended-rules into practical application that is truly meaningful and effective from the bottom-up perspective. 


\section{Conclusion}

Renewable energy in the Arctic takes several forms in this chapter, including hydro and wind power. Renewables transitions are predominantly led by government and corporate actors and framed in terms of technological and economic responses to environmental sustainability. These projects are often presented in pro-environmental terms of responding to climate change, shifting away from fossil fuels, and fitting into a governmental self-image of a "green society"

Contestation around renewables transition takes multiple forms, including landscape impacts, concerns with infrastructure siting, and social impacts. Indigenous communities and environmental groups are actors that create friction and raise questions about the potential downsides of renewables transitions.

Our overview shows that renewable energy projects that are promoted as part of necessary climate change action can have perversely negative impacts on community environmental health and safety as well as the traditions and income-generating activities of Arctic Indigenous groups. The need for energy justice underscores the importance of approaching climate change responses and renewable energy transitions in ways that adequately address local concerns and needs in a manner that is meaningful to those who may be adversely affected.

The urgency of mitigating climate change means a surge in renewable energy projects. While in line with the SDGs, in particular SDG 7 and 13, the examples above demonstrate the risk that such projects may cause social harm to local communities, including - but not limited to-Indigenous groups. This accentuates fundamental issues of environmental, energy and human rights justice, with strong connections between the environmental and social (including human rights) aspects. In turn, this underscores the pertinence of scholarship and practice considering the practical realisation of the SDG's implementation provision No 67 on not causing harm and acting in accordance with the UNGP's provisions. In an Arctic context it highlights that compliance with rules must be complemented by practices that consider and respect local experiences and perceptions of impacts.

A key take-away argument of this chapter is that as circumpolar countries grapple with the necessities of decarbonising energy systems in response to climate change, we see that renewable transitions will also create new points of tension. Renewable does not necessarily equal socially sustainable or just transitions. To address this actual or potential conflict with commitments under the SDG Declaration and the Paris Agreement, there is a need to move beyond governmental and corporate-led models of renewable transitions to more participatory, deliberative processes for ensuring a just renewables transition. Involvement of communities and other affected stakeholders including rights-holders may help uncover alternative placements and local benefits. Involvement of affected stakeholders can contribute to 
understanding and acceptance of unwelcome social impacts that are necessary for the green transition in the larger interest of responding to climate change. It may therefore contribute to transitions that are perceived and accepted as socially fair under the given circumstances. Although it does not eliminate difficult challenges around adverse impacts, it can help alleviate some of the social and moral dilemmas related to urgent action to mitigate climate change.

\section{Acknowledgements}

This chapter has benefitted from the following projects (funding agencies in brackets): NOS-HS project "Best practice for Impact Assessment of infrastructure projects in the Nordic Arctic: Popular participation and local needs, concerns and benefits" (Nordic Research Councils); University of the Arctic (UArctic) Thematic Network on Arctic Sustainable Resources and Social Responsibility (UArctic with the Danish Agency for Science and Higher Education); and the Insight Grant project The Oil-Tourism Interface and Social-Ecological Change in the North Atlantic (SSHRC).

\section{Note}

1. see Swiilawiid.org

\section{References}

Abram, S. (2016). Jokkmokk: Rapacity and resistance in Sápmi. In G. Huggan \& L. Jensen (Eds.), Postcolonial perspectives on the European high North, pp. 67-92. Palgrave.

Allard, C., \& Skogvang, S. F. (Eds.). (2017). Indigenous rights in Scandinavia: Autonomous Sámi law. Routledge.

Allen, V. (2017). Muskrat falls. In A. Marland and L. Moore (Eds.), The democracy cookbook: Recipes to renew governance in newfoundland and Labrador, pp. 318-320. ISER Books.

Bankes, N., \& Koivurova, T. (2013). The proposed Nordic Saami convention: National and international dimensions of indigenous property rights. Hart Pub.

Bakker, K., \& Hendriks, R. (2019). Contested knowledges in hydroeletric project assessment: The case of Canada's site c project. Water, 11(3). https://doi. org/10.3390/w11030406

Bavington, D. (2010). Managed annihilation: An unnatural history of the newfoundland cod collapse. UBC Press.

Bebbington, A., Bebbington, D. H., Bury, J., Lingan, J., Muñoz, J. P., \& Scurrah, M. (2008). Mining and social movements: Struggles over livelihood and rural territorial development in the Andes. World development, 36(12), 2888-2905.

Bhattacharya, A. (2017). Building A Network of Clean Energy Systems: A Case Study of T'Sou-Ke First Nation Solar Project [MA Thesis, University of Northern British Columbia]. Canadian Centre for Policy Alternatives. 
Bjørst, R. (2016). Saving or destroying the local community? Conflicting spatial storylines in the Greenlandic debate on uranium. The Extractive Industries and Society, 3(1), 34-40.

Buhmann, K., Sanne, V. L., \& Anna-Sofie, H. S. (2019/2020). Why consultations on large projects matter to citizens as well as companies, entry No 1 in blog-post series 'Consultations, Public Participation, and Meaningful Stakeholder Engagement' (Center of Business and Development, Copenhagen Business School), https:// www.cbds.center/post/blogpost-series-1-consultations-public-participationand-meaningful-stakeholder-engagement, republished in 2020 under the Business of Society BOS (CBS Center for Sustainability) blog series (http://www.bos-cbscsr. dk/2020/02/07/why-consultations-on-large-projects-should-matter-to-citizens-aswell-as-companies/).

Buhmann, K. (2018a). Neglecting the proactive aspect of human rights due diligence? A critical appraisal of the EU's non-financial reporting directive as a pillar one avenue for promoting pillar two action. Business and Human Rights Journal, 3(1), 23-45.

Buhmann, K. (2018b). Analyzing OECD national contact point statements for guidance on human rights due diligence: Method, findings and outlook. Nordic Journal of Human Rights, 36(4), 390-410.

Buhmann, K. (2016). Public regulators and CSR: The "Social licence to Operate" in recent United nations instruments on business and human rights and the juridification of CSR. Journal of Business Ethics, 136(4), 699-714.

Business Index North. (2017). Renewable energy in the North, business index North (Issue 1). Business Index North. https://businessindexnorth.com/sites/b/businessindexnorth.com/files/bin2017_5_renewable_energy_in_the_north_web.pdf

Buxton, A., \& Wilson, E. (2013). FPIC and the extractive industries: A guide to applying the spirit of free, prior and informed consent in industrial projects. International Institute for Environment and Development.

Byers, M. (2012, March 9). My Cage Fight in Fort McMurray. The Tyee. https:// thetyee.ca/Opinion/2012/03/09/Fight-In-Fort-McMurray/

Cambou, D. (2018). Renewable energy in the Arctic and the human rights of indigenous peoples: Past, present and future experiences of the Sámi people. In G. Xue, \& L. He (Eds.), Law and governance: Emerging issues of the polar regions (p. 291). Shanghai: China University of Political Science and Law Press.

Cambou, D., \& Polzer, G. (2020). Energy justice in the Arctic: The limits and challenges of the transition to renewable energy for Arctic indigenous peoples. In D. Natcher \& T. Koivurova (Eds.), Renewable economies in the Arctic: A state of knowledge. Routledge.

Cole, D. (2018). Muskrat Falls Symposium. Memorial University.

Cox, S. (2018a). Breaching the peace: The site $c$ dam and a Valley's stand against big hydro. On Point Press

Cox, S. (2018b, October 30). Be Prepared to Be Surprised: What's Next for Site C Dam?. The Narwhal. https://thenarwhal.ca/be-prepared-to-be-surprised-whatsnext-for-the-site-c-dam/

Cox, S. (2019a). A Reckoning for Muskrat Falls. The Narwhal. https://thenarwhal. ca/a-reckoning-for-muskrat-falls/

Cox, S. (2019b). Mercury rising: How the Muskrat Falls dam threatens Inuit way of life. The Narwhal. Retrieved from https://thenarwhal.ca/mercury-risingmuskrat-falls-dam-threatens-inuit-way-of-life/ 
Cunsolo, A., \& Ellis, N. R. (2018). Ecological grief as a mental health response to climate change-related loss. Nature Climate Change, 8(4), 275-281.

Doherty, T. (2018). Muskrat Falls Symposium. Memorial University.

Esteves, A. M., Franks, D., \& Vanclay, F. (2012). Social impact assessment: The state of The art. Impact Assessment and Project Appraisal, 30(1), 34-42.

Forester, J. (1989). Planning in the face of power. University of California Press.

Government of Greenland. (2016). Social Impact Assessment: Guidelines on the process and preparation of the SIA report for mineral projects. Ministry of Industry, Labour and Trade.

Government of Greenland. (2019). Oliestrategi 2019-2023. Government of Greenland. https://naalakkersuisut.gl/ /media/Nanoq/Files/Hearings/2019/Oliestrategi\%20 for $\% 202019 \_2023 /$ Documents/Oliestrategi $\% 202019-2023 \% 20$ DK\%204.pdf

Hansen, A. M., Vanclay, F., Croal, P., \& Skjervedal, A. S. H. (2016). Managing the social impacts of the rapidly-expanding extractive industries in Greenland. The Extractive Industries and Society, 3(1), 25-33.

Harrison, J. (2013). Establishing a meaningful human rights due diligence process for corporations: Learning from experience of human rights impact assessment. Impact Assessment and Project Appraisal, 31(2), 107-117.

Hoffmann, A. J. (2011). Talking past each other? Cultural framing of skeptical and convinced logics in the climate change debate. Organization \& Environment, 24, 3-33.

Hulme, M. (2009). Why we disagree about climate change: Understanding controversy, inaction and opportunity. Cambridge University Press

Human Rights Council. (2016). Report on the human rights situation of the Sámi people in the Sápmi region. United Nations Special Rapporteur on the Rights of Indigenous Peoples. http://unsr.vtaulicorpuz.org/site/index.php/en/documents/ country-reports/155-report-sapmi-2016

IFC. (2012). Guidance note no 5: Land acquisition and involuntary settlement. International Finance Corporation.

Kapoor, I. (2001). Towards participatory environmental management? Journal of Environmental Management, 63, 269-279.

Koivurova, T., Masloboev, V., Hossain, K., Nygaard, V., Petrétei, A., \& Vinogradova, S. (2015). Legal protection of Sámi traditional livelihoods from the adverse impacts of mining: A comparison of the level of protection enjoyed by Sámi in their four home States. Arctic Review on Law and Politics, 6(1), 11-51.

Lindahl, K. B., Johansson, A., Zachrisson, A., \& Viklund, R. (2018). Competing pathways to sustainability? Exploring conflicts over mine establishment in the Swedish mountain region, Journal of Environmental Management, 218.

Loo, T. (2007). Disturbing the peace: Environmental change and the scales of justice on a Northern River. Environmental History, 12(4), 895-919.

Maher, R., \& Buhmann, K. (2019). Meaningful stakeholder engagement: Bottom-Up initiatives within global governance frameworks. GeoForum. doi: https://doi. org/10.1016/j.geoforum.2019.06.013.

McCauley, D., Heffron, R., Pavlenko, M., Rehner, R., \& Holmes, R. (2016). Energy justice in the Arctic: Implications for energy infrastructural development in the Arctic. Energy Research \& Social Science, 16, 141-146.

Mestad, O. (2002). Rights to public participation in Norwegian mining, energy, and Resource development. In D. N. Zillman, R.L. Alastair, \& G. Pring (Eds.), Human rights in natural Resource development. Public participation in the sustainable development of mining and energy Resources (pp. 382-400). Oxford UP. 
Mohai, P., Pellow, D., \& Roberts, T. (2009). Environmental justice. Annual Review of Environment and Resources, 34, 405-430.

Municipal Affairs and Environment: Climate Change Branch. (2011). The Way Forward on Climate Change in Newfoundland and Labrador. Government of Newfoundland and Labrador. https://www.exec.gov.nl.ca/exec/occ/action_plans. html

Muir, B. (2018). Effectiveness of the EIA for the site c hydroelectric dam reconsidered: Nature of indigenous cultures, rights, and engagement. Journal of Environmental Assessment Policy and Management, 20(4). https://doi.org/10.1142/ S146433321850014X

Nalcor Energy. (2020). Muskrat Falls. Nalcor Energy. http://muskratfalls.nalcorenergy.com/

National Energy Board. (2018). Canada's Renewable Power Landscape 2016 Energy Market Analysis. Canada Regulator Regulator. https://www.neb-one. gc.ca/nrg/sttstc/lctrct/rprt/2016cndrnwblpwr/prvnc/bc-eng.html

Nenasheva, M., Bickford, S., Lesser, P., Koivurova, T., \& Kankaanpaa, P. (2015). Legal tools of public participation in the environmental impact assessment process and their application in the countries of the Barents Euro-Arctic region. Barents Studies, 1(3), 13-35.

Nukissiorfiit. (2019). Vindenergi. Nukissiorfiit. https://www.nukissiorfiit.gl/ vedvarende-energi/vindenergi/

Nuttall, M. (2012). The Isukasia iron ore mine controversy: Extractive industries and public consultation in Greenland. Nordica Geographical Publications, 41(5), 23-34.

OECD. (2011). OECD guidelines for multinational enterprises [rev. May 2011]. Organisation of Economic Cooperation and Development.

OECD. (2017). Due diligence guidance for meaningful stakeholder engagement in the extractive sector. OECD.

OECD Watch. (2012). Jijnjevaerie Saami village vs Statkraft - OECD watch case database. OECD. https://complaints.oecdwatch.org/cases/Case_280

Olsen, A. S. H., \& Hansen, A. M. (2014). Perceptions of public participation in impact assessment: A study of offshore oil exploration in Greenland. Journal of Impact Assessment and Project Appraisal, 32(1), 72-80.

Parenteau, R. (1988). Public participation in environmental decision-making. Minister of Supply and Services, Government of Canada.

Pearce, D. W., Edwards, L., \& Beuret, G. (1979). Decision-making for energy futures: A case study of the windscale inquiry. Macmillan, in association with the SSRC.

Penney, J. (2018). Muskrat Falls Symposium. Memorial University.

Philpott, E. (2018). Muskrat Falls Symposium. Memorial University.

Proctor, A., Felt, L., \& Natcher, D. C. (2012). Introduction. In D. C. Natcher, L. Felt, \& A. Proctor (Eds.), Settlement, subsistence, and change among the Labrador Inuit (pp. 3-13). University of Manitoba Press.

Rodríguez-Labajos, B., \& Özkaynak, B. (2017). Environmental justice through the lens of mining conflicts. Geoforum, 84, 245-250.

Ruggie, J. (2013). Just business. Norton.

Sejersen, F. (2014). Efterforskning og udnyttelse af råstoffer $i$ Grønland $i$ historisk perspektiv. Baggrundspapir. Udvalget for samfundsgavnlig udnyttelse af Grønlands naturresourcer. Ilisimatusarfik \& University of Copenhagen. 
Skjervedal, A. (2018). Towards Meaningful Youth Engagement: Breaking the Frame of the Current Public Participation Practice in Greenland [Ph.D. dissertation, Ilisimatusarfik - The University of Greenland and Aalborg University].

Sodero, S., \& Stoddart, M. C. (2015). A typology of diversion: legitimating discourses of tourism attraction, oil extraction and climate action in newfoundland and Labrador. Environmental Sociology, 1(1), 59-68.

Stanley, M. (2010). Voices from two rivers: Harnessing the power of the peace and Columbia. Douglas \& McIntyre.

Storholm, L. (2016). Sámi Parliament Council refers to Nussir as "the new Alta case”. High North News. https://www.highnorthnews.com/en/Sámi-parliamentcouncil-refers-nussir-new-alta-case

Tauxe, C. S. (1995). Marginalizing public participation in local planning: An ethnographic account. Journal of the American Planning Association, 61(4), 471-481.

Udofia, A., Noble, B., \& Poelzer, G. (2017). Meaningful and efficient? Enduring challenges to aboriginal participation in environmental impact assessment. Environmental Impact Assessment Review, 65, 164-174.

UN. (1998). Convention on Access to Information, Public Participation in DecisionMaking and Access to Justice in Environmental Matters (Aarhus Convention). United Nations.

UN. (2008). Protect, respect and remedy: A framework for business and human rights, Report of the Special Representative of the Secretary-General on the issue of human rights and transnational corporations and other business enterprises, John Ruggie (UN Doc. A/HRC/8/5). United Nations Human Rights Council.

UN. (2011). Guiding Principles on Business and Human Rights: Implementing the United Nations "Protect, Respect and Remedy" Framework (UN Doc. A/ HRC/17/31). United Nations Human Rights Council.

UN. (2015a). Transforming our world: the 2030 Agenda for Sustainable Development (UN Doc. A/Res/70/1). United Nations.

UN. (2015b). Framework Convention on Climate Change - Conference of the Parties: Adoption of the Paris Agreement (UN Doc. FCCC/CP/2015/L.9/Rev.1). United Nations.

Vanclay, F. (2003). International principles for social impact assessment. Journal of Impact Assessment and Project Appraisal, 21(1), 5-11.

Vanclay, F., Esteves, A.M., 2011. New Directions in Social Impact Assessment: Conceptual and Methodological Advances. Edward Elgar Publishing, Cheltenham, UK.

Webler, T., Kastenholz, H., \& Renn, O. (1995). Public participation in impact assessment: A social learning perspective. Environmental Impact Assessment Review, 15, 443-463.

Wettstein, F. (2012). Human rights as a critique of instrumental CSR: Corporate responsibility beyond the business case. Notizie de POLITEIA, 116, 18-33.

Zoomers, E. A., \& Otsuki, K. (2017). Addressing the impacts of large-scale land investments: Re-engaging with livelihood research. Geoforum, 83, 164-171. 